\title{
Macrophyte functional composition is stable across a strong environmental gradient of a Neotropical floodplain
}

\section{Suelen C. A. da Silva Pereto ${ }^{1}$ (1) and Andre Andrian Padial, 2, 3* (1)}

Received: July 24, 2020

Accepted: November 24, 2020

\begin{abstract}
Ecological communities are compared by the similarity or distinctness of their species. Taking into account community composition at a determined site, one could expect a similar reasoning to explain differences in both taxonomic and functional composition due to environmental gradients. We aim to evaluate spatial variation in functional composition of aquatic macrophyte assemblages in a Neotropical floodplain. The studied floodplain is characterized by encompassing different ecoregions considering both differences in environmental features and macrophyte taxonomic composition. Therefore, we hypothesized that macrophyte functional composition would differ among ecoregions but instead found limited differences in functional composition. There was only a little evidence that some life forms are more or less observed in certain ecoregions. Thus, the considerable environmental heterogeneity found at the ecoregion scale is reflected only in taxonomic, and not in functional composition. This result can be explained by different species having high functional redundancy: different functional traits could be recorded in all ecoregions. Therefore, we suggest that the functioning of the entire ecosystem is probably insured by species functional redundancy in this Neotropical floodplain. Nonetheless, we cannot rule out the fact that trait choice could affect interpretations, and so trait selection should be better explored, particularly for aquatic macrophytes.
\end{abstract}

Keywords: community structure, environmental filtering, functional traits, floodplain, redundancy

\section{Introduction}

Two major ecological processes are reported as possibly responsible for structuring communities: limiting similarity and environmental filters (Pausas \& Verdú 2010), particularly at scales with poor dispersal limitation (Vellend 2010). Limiting similarity considers that species co-occur at determined sites due to functional trait distinction. Therefore, resource exploitation is different among species, resulting in low niche overlap (Tilman 2001; Pocheville 2015). Low niche overlap usually ensures species co-occurrence (Diamond 1975; Cazelles et al. 2016). High niche overlap means a common use of resources, likely resulting in local species competitive exclusion when resources are limited (Pocheville 2015), even though small niche differences have been reported as enough for species coexistence (Chesson 2000). Environmental filtering, in turn, is known as the effect of environmental factors selecting species, allowing their establishment, survival, reproduction and persistence in a suitable site (Heino et al. 2015). In a set of different ecoregions, environmental filters may cause dissimilarity in both taxonomic and functional composition (Lamarre et al. 2016; Lozada-Gobilard et al.

\footnotetext{
1 Laboratório de Análise e Síntese em Biodiversidade, Pós-Graduação em Ecologia e Conservação, Setor de Ciências Biológicas, Universidade Federal do Paraná, 81531-990, Curitiba, PR, Brazil

2 Pós-Graduação em Botânica, Setor de Ciências Biológicas, Universidade Federal do Paraná, 81531-990, Curitiba, PR, Brazil

3 Núcleo de Pesquisa em Limnologia, Ictiologia e Aquicultura, Programa de Pós-Graduação em Ecologia de Ambientes Aquáticos Continentais,

Universidade Estadual de Maringá, 87020-900, Maringá, PR, Brazil
}

* Corresponding author: aapadial@gmail.com 
2019). On the other hand, if environmental filters are transposed (particularly in groups with high environmental plasticity), species may exhibit high functional similarity enabling niche overlap and resource competition (Funk et al. 2008; Weiher et al. 2011) decreasing species relative abundances and promoting competitive exclusion (Garrett 1960; Tilman 2001). The aforementioned mechanisms explain why taxonomic compositional differences are not always related to functional compositional dissimilarities.

Environmental filtering is common mainly when the environmental gradient is wide and results in species pool selection, causing metacommunity local differences (Padial et al. 2014). More than taxonomic differences, trait-based community assembly patterns along environmental gradients allow a better understanding of functional differences at different spatial and temporal scales (Pillar et al. 2009; García-Girón et al. 2019), and may contribute in creating more quantitative and predictive community ecology (McGill et al. 2006). One may expect that if taxonomic composition differs in response to environmental filtering, functional composition may also differ (Lamarre et al. 2016). On the other hand, taxonomic differences may be generated by dynamic processes of colonization and competitive exclusion of functionally similar species; the taxonomic differences are not always reflected in differences of functional composition (Pavao-Zuckerman \& Coleman 2007).

Previous studies have shown clear taxonomic differences related to ecoregions, which are here defined as groups of aquatic habitats associated to different rivers inside a Neotropical floodplain with different environmental characteristics caused by the influence of different rivers (Padial et al. 2009; 2012). Ecoregions in this floodplain differ especially considering limnological, geomorphological and biological features, which define the major ecological gradient (Roberto et al. 2009) that explains overall biodiversity (Santos \& Thomaz 2007; Thomaz et al. 2009). Therefore, the overall suggestion is that environmental filtering related to ecoregions is strong in the floodplain, causing community assembly (Bini et al. 2001; Thomaz et al. 2009; Padial et al. 2012). However, the evidence above is limited to taxonomic composition. Particularly for aquatic macrophyte dynamics, their response to ecological filters has been usually understood using functional traits as response variables (Shipley et al. 2011).

Environmental filtering in functional composition of aquatic macrophytes has strong implications for ecosystem functioning, given the role of aquatic macrophytes in structuring aquatic ecosystems, affecting diversity and ecological relations (Jeppesen et al. 1998; Meerhoff et al. 2003; Cunha et al. 2011). Relatedly, Tilman et al. (1997) highlighted that understanding variations in functional composition is essential for knowledge of ecosystem processes (see also Cadotte et al. 2011). Here, we tested the hypothesis that functional composition of aquatic macrophyte communities differ among ecoregions of a Neotropical floodplain, following a clear taxonomic difference. We used functional metrics to describe the variation in functional composition of aquatic macrophyte assemblages over 15 sampling sites in the Upper Paraná River floodplain (UPRF). Consequently, environmental filtering may also affect 'ecosystem functionality' of the floodplain, mainly considering the well-recognized functional role of aquatic macrophytes (Pandit 1984).

\section{Materials and methods}

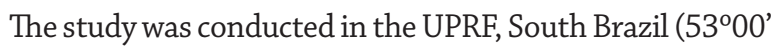

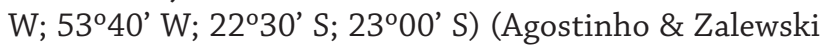
1996). The Upper Paraná River floodplain climate is classified as tropical and subtropical (according to the Köppen system), with annual average temperature around $22^{\circ} \mathrm{C}$ and the annual average precipitation around $1500 \mathrm{~mm}$ (Souza-Filho 2009). The flood period is usually from October to March, and the drought period usually from June to September (Roberto et al. 2009). Although environmental changes have been observed due to anthropogenic pressures related to upstream and downstream damming, the record of well-developed and diversified aquatic macrophyte communities (Thomaz et al. 2002; Ferreira et al. 2011; Souza et al. 2017) reinforces the fact that the UPRF is an important biodiversity hotspot for aquatic communities (Ferreira et al. 2011). Environmental differences of three hydrological ecoregions are considered the major environmental gradient in the UPRF. Such ecoregions (named as "Paraná", "Baia" and "Ivinhema") are characterized by a main river channel and several associated lakes. Ecoregions differ from each other giving their distinct geomorphological origins and features (source of organic matter, water flow, limnological variables, etc.) (Roberto et al. 2009). The Paraná River is the most important to the water level fluctuations in the Upper Paraná River floodplain. The Ivinhema and Baía rivers contribute to the inundation of habitats adjacent to their margins, making their associated lakes functionally distinct among three river systems (Souza-Filho 2009). Lakes associated to Ivinhema River usually have higher organic matter and nutrient contents, whereas lakes associated to Baia River have high humic compounds and lower $\mathrm{pH}$, and lakes associated to Paraná River have higher transparency, lower nutrients and organic compounds and higher water flow (Roberto et al. 2009). Sampled lakes are shallow, varying from c. $0.10 \mathrm{~m}$ depth during drought periods in the shallowest lake to c. $8 \mathrm{~m}$ depth during flood periods at the deepest lake. They also varied widely in area, from approximately 0.006 ha to 113.8 ha (see also Thomaz et al. 2009).

We have sampled aquatic macrophytes, following Pedralli et al. (1990) classification, from five different lakes of each of the three ecoregions of the UPRF in November 2015. Species were collected along the entire shoreline of all lakes and maintained moisture in $100 \mathrm{~L}$ plastic bags until identification and trait measurements. The sampling methodology 
followed Pérez-Harguindeguy et al. (2013), which proposed a module sampling for vegetative propagation species. A module can be described as the simplest minor repeating portion containing root, stem and leaves. This methodology was established giving the intense vegetative propagation of aquatic macrophyte species, making the identification of an individual very difficult. For each module, we chose 17 functional traits (Tab. 1) in order to assess aquatic macrophyte functional composition. All traits are shown to be related to species response to environmental features: see in List S1 in supplementary material for details and justification of chosen traits. Ten (10) of the chosen traits were continuous or measurable in the modules, and were thus directly measured in the field. The other seven (7) traits refer to species-specific features that do not vary among modules, so they were obtained directly from the literature describing species ecomorphological traits.

Table 1. List of functional traits chosen to describe aquatic macrophytes functional composition, indicating traits obtained from literature information, or directly measured after field sampling.

\begin{tabular}{|c|c|c|}
\hline & Classification & Traits \\
\hline \multirow{19}{*}{$\begin{array}{l}\text { Obtained from } \\
\text { literature }\end{array}$} & \multirow{12}{*}{ Plant } & Amphibious \\
\hline & & Emergent \\
\hline & & Epiphyte \\
\hline & & Fixed floating \\
\hline & & Free floating \\
\hline & & Fixed Submerged \\
\hline & & Free Submerged \\
\hline & & Annual \\
\hline & & Perennial \\
\hline & & Monthly blooming \\
\hline & & Semester blooming \\
\hline & & Annual blooming \\
\hline & \multirow{4}{*}{ Leaf } & Glabrous pilosity \\
\hline & & Pilous pilosity \\
\hline & & Coriaceous consistency \\
\hline & & Herbaceous consistency \\
\hline & \multirow{2}{*}{ Stem } & Erect \\
\hline & & Prostrate \\
\hline & Root & $\begin{array}{c}\text { Fasciculate } \\
\text { Pivoting }\end{array}$ \\
\hline \multirow{10}{*}{$\begin{array}{l}\text { Measured in the } \\
\text { laboratory }\end{array}$} & Plant & Height $(\mathrm{cm})$ \\
\hline & \multirow{3}{*}{ Leaf } & Width $(\mathrm{cm})$ \\
\hline & & Length $(\mathrm{cm})$ \\
\hline & & Thickness (mm) \\
\hline & \multirow{2}{*}{ Petiole } & Length (mm) \\
\hline & & Presence/ absence \\
\hline & \multirow{2}{*}{ Stem } & Thickness (mm) \\
\hline & & Presence/ absence \\
\hline & \multirow{2}{*}{ Root } & Length $(\mathrm{cm})$ \\
\hline & & Presence/ absence \\
\hline
\end{tabular}

Traits related to morphology, growth and life form have been commonly used to describe how environmental conditions (Ali et al. 1999; Griffin-Nolan et al. 2018) affect the reproduction, growth and species survival (Cavalli et al. 2014). We thus expect that the chosen traits represent functional composition variation along environmental gradients. For instance: i) emergent species are usually the most abundant (Thomaz et al. 2002; Alves-da-Silva et al. 2014) occurring in shallow belts and along the riverside (Pott et al. 1989); ii) submerged species occur when transparency is high (Bornette \& Puijalon 2011); iii) free-floating species are abundant in high nutrient concentration in water column (Bornette \& Puijalon 2011); iv) fasciculate roots for aquatic macrophytes develop an important role guaranteeing air reserve (allowing floating) and rapid nutrient achievement (e.g., the architecture of fasciculate roots promotes a higher area for nutrient assimilation) (Tabata et al. 2015; Pereto et al. 2016); v) the presence of trichomes on leaf blades could be efficient as a mechanical barrier against herbivores and/ or pathogens (Werker, 2000) and guarantee a micro-climate around the stomata avoiding water loss (Buckley 2005); and so on (see further details in Supporting Information).

We were unable to use physiologic traits due to uncommon use, high costs and difficulty in estimations (Zhang 2004). However, we believe that, at least for our main goal, the chosen traits fulfill the mission in describing functional composition among different ecoregions given the fact that many functional traits translate important physiologic aspects (leaf morphologic aspects are linked to photosynthesis).

The functional composition of the aquatic macrophyte communities was measured by the community-level weighted means of trait values (CWM) (Lavorel et al. 2008). In this case, matrices of species presence/absence per ecoregion and species per trait were created for all 15 lakes (five from each ecoregion). A Principal Coordinate Analysis (PCoA) was used to visualize patterns in functional composition. We formally tested for differences in functional composition among ecoregions using a Permanova (Anderson et al. 2001). The same analyses above were made for presence/absence taxonomic composition, which was made only to describe the already known differences among ecoregions (Padial et al. 2009), as anticipated (see Results). To characterize typical species per ecoregion, we then used an indicator value analysis (IndVal - Dufrêne \& Legendre 1997). Species with high IndVal values indicate species that i) occurs mostly in one ecoregion and ii) in most sampling lakes of such ecoregion (the "specificity" and "fidelity" facets of IndVal, respectively; Dufrêne \& Legendre 1997). Whereas Permanova statistically tests differences in species composition, IndVal indicates which species mostly contributed to such compositional differences. For all analyses above, we used the following functions and packages in $R$ environment $(R$ Development Core Team 2018): function 'functcomp' for functional composition in the "FD" package (Laliberté et al. 2014), functions 'pco' for PCoA and 'indval' for IndVal in "labdsv" package (Roberts 2016), and functions 'vegdist' for distance matrices and 'adonis' for Permanova in "vegan" package (Oksanen et al. 2017). 


\section{Results}

Forty-six (46) species of aquatic macrophytes were recorded in the fifteen sampled lakes of the UPRF (Tab. 2). As anticipated, the three ecoregions (Paraná, Baia and Ivinhema) clearly differ from each other considering taxonomic biodiversity (Permanova: $\mathrm{F}=3.28, \mathrm{R}^{2}=0.35$, $P=0.001$ ) (Fig. 1A). According to the IndVal, Paraná ecoregion had Ludwigia peruviana as an indicator species (IndVal=1, $P=0.001$ ) occurring in the five lakes sampled. Limnobium laevigatum was an indicator species of Baia ecoregion (IndVal=0.8, $P=0.01$ ) occurring in four of the five lakes sampled. Ivinhema ecoregion had no indicator species.

On the other hand, functional composition did not significantly differ among ecoregions $\left(\mathrm{F}=1.41, \mathrm{R}^{2}=0.19\right.$, $P=0.238$ ) (Fig. 1B). The only patterns that can be suggested considering the PCoA, albeit weak, are: i) emergent life form species seems to be typical in nearly all lakes of the Paraná ecoregion (Fig. 1B) and ii) fasciculate roots were mostly observed in lakes from Baia and Ivinhema ecoregions (Fig. 1B).
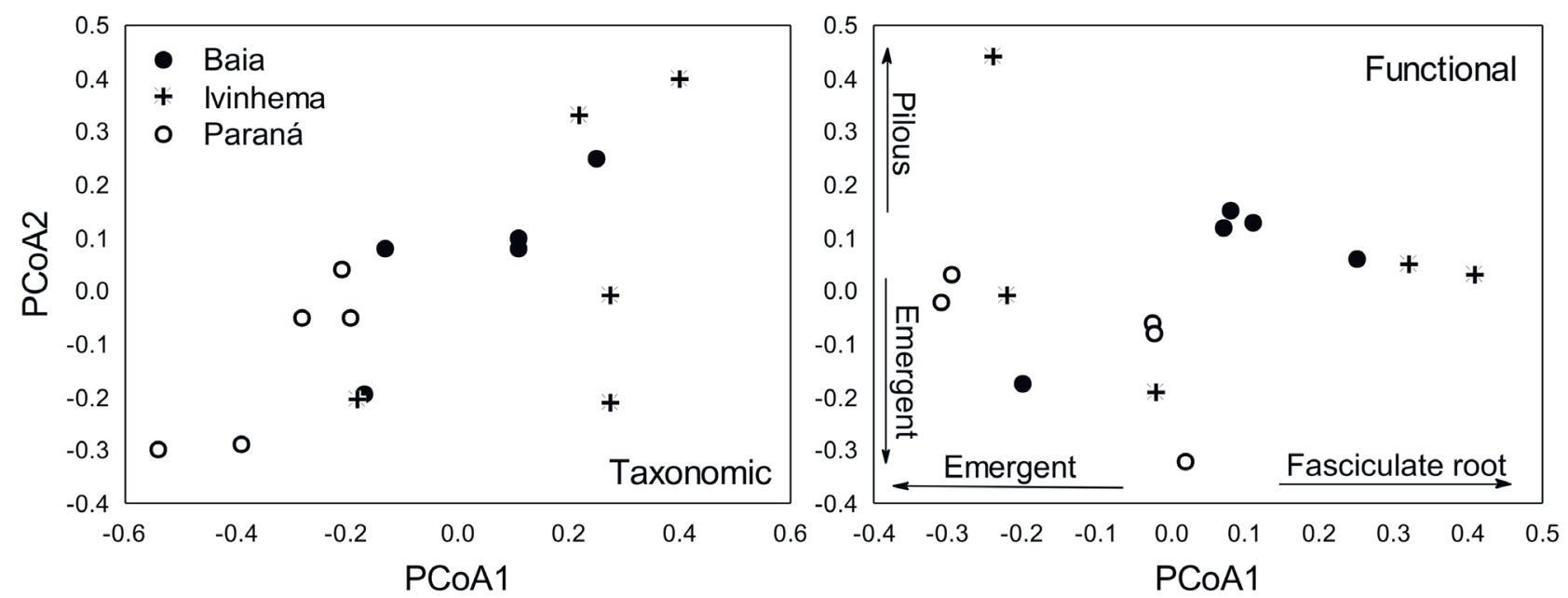

Figure 1. Principal Coordinate Ordination Analyze (PCoA) from the aquatic macrophytes of the three ecoregions of the Upper Paraná River Floodplain considering $\mathbf{A}$ ) taxonomic diversity (presence/absence) and; B) functional composition.

Table 2. Recorded macrophyte species in the 15 lakes sampled to test for differences in taxonomical and functional composition in the Upper Paraná River Floodplain.

\begin{tabular}{|c|c|}
\hline Recorded species & Recorded species (cont.) \\
\hline Aeschynomene sensitiva Sw. & Ludwigia leptocarpa (Nutt.) Hara. \\
\hline Alternanthera philoxeroides (Mart.) Griseb & Ludwigia octovalvis (Jacq) Raven \\
\hline Azolla filiculoides Lamarck & Ludwigia peruviana (L.) H. Hara \\
\hline Cabomba caroliniana A. Gray & Mimosa setosa Benth. \\
\hline Cabomba furcata Schult. & Myriophyllum brasiliensis Camb. \\
\hline Commelina nudiflora L. & Nymphaea amazonum Mart. \& Zucc. \\
\hline Cuphea melvilla Lindlay & Oxycaryum cubense (Poep. \& Kunth) \\
\hline Diodia brasiliensis Spreng. & Paspalum repens Berg. \\
\hline Egeria najas Planch. & Pistia stratiotes L. \\
\hline Pontederia azurea (Sw.) & Polygonum acuminatum Kunth. \\
\hline Pontederia crassipes Mart. & Polygonum punctatum Elliott \\
\hline Fuirena sp. & Polygonum stelligerum Cham. \\
\hline Habenaria repens Nuttall & Pontederia cordata var lanceolata (Nutt.) Griseb. \\
\hline Hibiscus striatus Cav. & Rhynchospora corymbosa (L.) Britton \\
\hline Hydrocotyle ranunculoides L.fil. & Ricciocarpus natans (L.) Corda \\
\hline Hymenachne amplexicaulis (Rudge) Nees. & Sagittaria montevidensis Cham. \& Schltdl. \\
\hline Hyptis mutabilis (Rich.) Briq. & Salvinia auriculata Aubl. \\
\hline Ipomoea carnea subs. fistulosa (Martius and Choise) & Salvinia herzogii de la Sota \\
\hline Leersia hexandra Sw. & Salvinia mínima Baker. \\
\hline Limnobium laevigatum Humb. \& Bonpl. ex Willd. & Scleria gaertneri Raddi \\
\hline Ludwigia grandiflora (Michx.) Greuter \& Burdet & Thalia geniculata L. \\
\hline Ludwigia helminthorrhiza (Mart.) H.Hara & Utricularia foliosa L. \\
\hline Ludwigia lagunae (Morong) H. Hara & Utricularia gibba L. \\
\hline
\end{tabular}




\section{Discussion}

In this study, we have tested if spatial variation of the aquatic macrophytes functional composition responds to environmental classification considering three different ecoregions in a Neotropical floodplain. Contrary to the observed taxonomic composition, there is poor functional composition differentiation among the ecoregions that are clearly heterogeneous considering multiple ecological features. Environmental heterogeneity has long since been described as a biodiversity predictor (Yang et al. 2015; Bergholz et al. 2017; Pinha et al. 2017). Heterogeneous sites promote species sorting, resulting in beta diversity among local communities of a metacommunity (Pinha et al. 2017; García-Girón et al. 2019). This was already demonstrated in the UPRF for several biological groups, ranging from microscopic algae to fish (Padial et al. 2012).

It has also been shown that environmental filtering can shape functional composition at different environmental sites, as a result of recruitment and establishment of species with different traits (Fortunel et al. 2014, Lozada-Gobilard et al. 2019). Therefore, it is interesting that the considerable environmental heterogeneity at the ecoregion scale in the UPRF is reflected only in taxonomic, but not in functional composition. Although not properly studied yet, functional composition can be related to other local peculiarities and characteristics unrelated to environmental classification in ecoregions, such as the area, depth or margin development of lakes (see also Monção et al. 2012). We initially expected that environmental filtering promoted by ecoregions could select species with similar functional features within an ecoregion, and different functional features between ecoregions. Our results show the opposite: a 'functional similarity' among ecoregions, indicating that different species from ecoregions are functionally redundant (see also Kang et al. 2015). At a finer scale, within ecosystems, functionally similar species may co-occur less often given that they may explore resources in a similar way. Therefore, one explanation for our results may be related to a relatively lower co-existence of functionally similar species within an ecoregion, as expected in limiting similarity theory (Abrams 1983).

Considering functional beta diversity, if turnover mostly drive compositional changes at larger scales, one expects functional variation among ecoregions. Even so, a previous study has suggested functional nestedness seems to be a common component of functional beta diversity at larger spatial scales (Fu et al. 2019), which can also help to explain that, taken the floodplain as a whole, redundancy of functional composition among ecoregions is not unexpected. As a consequence, functionally similar species can be observed among ecoregions. Considering the ecological mechanisms behind functional patterns, it is most likely that an interaction of deterministic and stochastic factors affects community structure considering taxonomic and functional compositions of macrophytes (García-Girón et al. 2019). In our study, both mechanisms may occur at different scales: between and within ecoregions (see also Padial et al. 2014), but our results at least suggest that the known taxonomic differences among ecoregions and a possible relatively lower co-existence of functionally similar species within ecoregions may be linked to a same underlying process.

We must highlight that our results do not necessarily indicate that the functional redundancy among ecoregions is a result of a decline in specialist species (as suggested by Clavel et al. 2011), which could have consequences to ecosystems functioning and productivity. Only longterm studies reporting a decline in functional diversity indexes could state that functional homogenization is a concern of ecosystem functioning. Indeed, future studies could use long-term data to compare functional variability among ecoregions, and thus test if ecoregions differ not in functional composition (as tested here), but in spatial and temporal variability of functional composition. Also, the fact that ecoregion classification was a poor predictor of functional composition does not mean that environmental filtering is unimportant to explain differences of functional traits or ecosystem functioning (Karadimou et al. 2016; García-Girón et al. 2019). For instance, functional trait variation can occur within a same lake due to local-scale environmental filtering; or even at larger spatial scales but depending on environmental changes over time. Indeed, strong temporal changes in both environmental features and community composition are observed due to the overwhelming driving force of the hydrological regime of the UPRF (Padial et al. 2009; Thomaz et al. 2009). Thus the environment may have a central role in filtering species traits independently of the similarities in functional composition observed at the ecoregion scale in our study.

Here, we investigated traits that usually respond to environmental variation, as those related to life form, roots and leaves (see Materials and methods, and in List S1 in supplementary material). At least for the scale observed in our study, even a strong environmental gradient (see Roberto et al. 2009) was not enough to promote functional differences, even though a clear compositional difference is observed. Maybe, differences could be observed in other scales, or considering other dimensions (e.g., temporal differences related to the well-known hydrological regime of floodplains). Also, we used in this study presence/absence data to infer community composition, but abundance can reveal other patterns. Macrophyte beds are usually dominated by a few species (Pott et al. 2011), which can have disproportionate roles in ecosystem functioning (Engelhardt \& Ritchie 2001). Our study is a first step, but considering abundance in functional community composition should be encouraged in future studies. 
Still, the lack of functional composition differentiation could also be explained by traits considered. We can never rule out that the choice of traits may affect interpretations (Zhu et al. 2017). Indeed, aquatic macrophytes have an extreme plasticity in morphological measurements ( $\mathrm{Li}$ et al. 2016), and this ensures ecosystem functioning when a community is composed by species with different traits (Jackrel \& Morton 2018). Therefore, some coarse (but classical) classifications may be more meaningful to consider the similarity in plant functions and response to environmental gradients, such as the life form classification (see also Schneider et al. 2018).

On the other hand, some authors argue that more details in traits are necessary to understand aquatic macrophyte responses to the environment (Gratani 2014). For instance, Steffens \& Rasmussen (2016) highlight the possible relevance in considering not only adventitious (or fasciculate) roots or not but classify it in types of adventitious roots (flood, nutrient or wound induced). In accordance to these authors, each type of adventitious root is regulated and responds to the submitted environmental condition in different ways (Steffens \& Rasmussen 2016). Taking into account the importance in choosing traits related to the ecological question to be answered (Diaz et al. 2013; Zhu et al. 2017; Griffin-Nolan et al. 2018) and how the chosen traits can maximize ecosystem function (Cadotte 2017; Fu et al. 2018), we encourage future studies to explore in details which traits should be used to test for different ecological hypotheses.

Functional traits biodiversity promotes ecosystem functioning giving the capacity of species in exploiting resources at different spaces and time (Fetzer et al. 2015; Gross et al. 2017). Here, we have shown that environmental filtering acting in taxonomic composition does not always select different functional composition, indicating that ecological studies may encompass different facets of biodiversity for a better link between biodiversity and ecosystem functioning. Functional redundancy is important to ensure higher stability to the ecosystem, given that if some species' populations are decreased, the redundant ones can keep ecological functions (Yachi \& Loreau 1999). Therefore, we suggest that the functional redundancy of species among ecoregions may promote insurance for whole ecosystem functioning of the floodplain.

\section{Acknowledgements}

We acknowledge PEA/Nupelia researchers for their logistic assistance and database assessment; CNPq and Capes for their financial support. S.C.A.P. received a doctorate scholarship from CAPES (Financial Code 001). A.A.P. is particularly grateful for continuous $\mathrm{CNPq}$ research grants (Project numbers: 307984/2015-0; 402828/2016-0; 301867/2018-6).

\section{References}

Abrams P. 1983. The theory of limiting similarity. Annual Review of Ecology and Systematics 14: 359-376.

Agostinho AA, Zalewski M. 1996. A planície alagável do alto rio Paraná: importância e preservação. Maringá, Editora da Universidade Estadual de Maringá.

Ali MM, Murphy KJ, Abernethy VJ. 1999. Macrophyte functional variables vs. species assemblages as predictors of trophic status in flowing waters. Hydrobiologia 415: 131-138.

Alves-da-Silva SC, Cervi AC, Padial AA. 2014. Aquatic macrophyte community varies in urban reservoirs with different degrees of eutrophication. Acta Limnologica Brasiliensia 26: 129-142.

Anderson MJ. 2001. A new method for non-parametric multivariate analysis of variance. Austral Ecology 26: 32-46.

Bergholz K, May F, Giladi I, Ristow M, Ziv Y, Jeltsch F. 2017. Environmental heterogeneity drives fine-scale species assembly and functional diversity of annual plants in a semi-arid environment. Perspectives in Plant Ecology, Evolution and Systematics 24: 138-146.

Bini LM, Thomaz SM, Souza DC. 2001. Species Richness and $\beta$-diversity of aquatic macrophytes in the Upper Paraná River Floodplain. Archiv fur Hydrobiologie 151: 511-525.

Buckley TN. 2005. The control of stomata by water balance. New Phytologist 168: 275-92

Bornette G, Puijalon S. 2011. Response of aquatic plants to abiotic factors: A review. Aquatic Sciences 73: 1-14.

Cadotte MW, Carscadden K, Mirotchnick N. 2011. Beyond species: functional diversity and the maintenance of ecological processes and services. Journal of Applied Ecology 48: 1079-1087.

Cadotte MW. 2017. Functional traits explain ecosystem function through opposing mechanisms. Ecology Letters 20: 989-996.

Cavalli G, Baattrup-Pedersen A, Riis T. 2014. The role of species functional traits for distributional patterns in lowland stream vegetation. Freshwater Science 33: 1074-1085.

Cazelles K, Araújo MB, Mouquet N, Gravel D. 2016. A theory for species co-occurrence in interaction networks. Theoretical Ecology 9: 39-48.

Chesson P. 2000. Mechanisms of maintenance of species diversity. Annual Review of Ecology, Evolution, and Systematics 31: 343-366.

Clavel J, Julliard R, Devictor V. 2011. Worldwide decline of specialist species: toward a global functional homogenization? Frontiers in Ecology and the Environment 9: 222-228.

Cunha ER, Thomaz SM, Evangelista HBA, Carniatto J, Souza CF, Fugi R. 2011. Small-sized fish assemblages do not differ between a native and a recently established non-indigenous macrophyte in a Neotropical ecosystem. Natureza \& Conservação. Brazilian Journal of Nature and Conservation 9: 61-66.

Diamond, JM. 1975. Assembly of Species Communities. In: Diamond JM, Cody ML. (eds.) Ecology and Evolution of Communities. Boston, Harvard University Press. p 342-344.

Diaz S, Purvis A, Cornelissen JHC, et al. 2013. Functional traits, the phylogeny of function, and ecosystem service vulnerability. Ecology and Evolution 3: 2958-2975.

Dufrêne M, Legendre P. 1997. Species assemblages and indicator species: the need for a flexible asymmetrical approach. Ecological Monographs 67: 345-366.

Engelhardt KAM, Ritchie ME. 2001. Effects of macrophyte species richness on wetland ecosystem functioning and services. Nature 411: 687-689.

Ferreira FA, Mormul RP, Thomaz SM, Pott A, Pott VJ. 2011. Macrophytes in the Upper Paraná River floodplain: checklist and comparison with other large South American wetlands. Revista de Biologia Tropical 59: 541-556.

Fetzer I, Johst K, Schäwe R, Banitz T, Harms H, Chatzinotas A. 2015. The extent of functional redundancy changes as species' roles shift in different environments. Proceedings of the National Academy of Sciences of the United States of America 112: 14888-14893.

Fortunel C, Paine CET, Fine PVA, Kraft NJB, Baraloto C. 2014. Environmental factors predict community functional composition in Amazonian forests. Journal of Ecology 102: 145-155. 
Fu H, Yuan G, Lou Q, et al. 2018. Functional traits mediated cascading effects of water depth and light availability on temporal stability of a macrophyte species. Ecological Indicators 89: 168-174.

Fu H, Yuan G, Jeppesen E, et al. 2019. Local and regional drivers of turnover and nestedness components of species and functional beta diversity in lake macrophyte communities in China. Science of the Total Environment 687: 206-217.

Funk JL, Cleland EE, Suding KN, Zavaleta ES. 2008. Restoration through reassembly: Plant traits and invasion resistance. Trends in Ecology \& Evolution 23: 695-703.

García-Girón J, Fernández-Aláez C, Fernández-Aláez M, Alahuhta J. 2019. Untangling the assembly of macrophyte metacommunities by means of taxonomic, functional and phylogenetic beta diversity patterns. Science of The Total Environment 693: 133616. doi: 10.1016/j. scitotenv.2019.133616

Garrett H. 1960. The competitive exclusion principle. Science 131: 12921297.

Gratani L. 2014. Plant Phenotypic Plasticity in Response to Environmental Factors. Advances in Botany 2014: 1-17.

Griffin-Nolan RJ, Bushey JA, Carroll CJW,et al. 2018. Trait selection and community weighting are key to understanding ecosystem responses to changing precipitation regimes. Functional Ecology 32: 1746-1756.

Gross N, Bagousse-Pinguet YL, Liancourt P, Berdugo M, Gotelli NJ, Maestre FT. 2017. Functional trait diversity maximizes ecosystem multifunctionality. Nature Ecology \& Evolution 1: 1-9.

Heino J, Melo AS, Bini LM. 2015. Reconceptualizing the beta diversityenvironmental heterogeneity relationship in running water systems. Freshwater Biology 60: 223-235.

Jackrel SL, Morton TC. 2018. Inducible phenotypic plasticity in plants regulates aquatic ecosystem functioning. Oecologia 186: 895-906.

Jeppesen E, Lauridsen TL, Kairesalo T, Perrow MR. 1998. Impact of submerged macrophytes on fish-zooplankton interactions in lakes. In: Jeppesen E, Søndergaard Ma, Søndergaard Mo, Christoffersen K. (eds.) The structuring role of submerged macrophytes in lakes. New York, Velarg, Springer Science \& Business Media. p. 91-114.

Kang S, Ma W, Li FY, Zhang Q, Niu J, Ding Y. 2015. Functional Redundancy Instead of Species Redundancy Determines Community Stability in a Typical Steppe of Inner Mongolia. PLOS ONE 10: e0145605. doi: 10.1371/journal.pone.0145605

Karadimou EK, Kallimanis AS, Tsiripidis I, Dimopoulos P. 2016. Functional diversity exhibits a diverse relationship with area, even a decreasing one. Scientific Report 6: 1-9.

Laliberté E, Legendre P, Shipley B. 2014. FD: measuring functional diversity from multiple traits, and other tools for functional ecology. R package version 1.0-12. https://cran.r-project.org/web/packages/FD/FD.pdf.

Lamarre GPA, Herault B, Fine PVA, et al. 2016. Taxonomic and functional composition of arthropod assemblages across contrasting Amazonian forests. Journal of Animal Ecology 85: 227-239.

Lavorel S, Grigulis K, McIntyre S, et al. 2008. Assessing functional diversity in the field - methodology matters! Functional Ecology 22: 134-147.

Li L, Geng Y, Lan Z. 2016. Phenotypic plasticity of aquatic plants in heterogeneous environments: a review. Biodiversity Science 24: 216227.

Lozada-Gobilard S, Stang S, Pirhofer-Walzl K, et al. 2019. Environmental filtering predicts plant-community trait distribution and diversity: Kettle holes as models of meta-community systems. Ecology and Evolution 9: 1898-1910.

McGill BJ, Enquist BJ, Weiher E, Westoby M. 2006. Rebuilding community ecology from functional traits. Trends in Ecology \& Evolution 21: 178-185.

Meerhoff M, Mazzeo N, Moss B, Rodríguez-Gallego L. 2003. The structuring role of free-floating versus submerged plants in a subtropical shallow lake. Aquatic Ecology 37: 377-391.

Monção FS, Santos AM, Bini LM. 2012. Aquatic macrophyte traits and habitat utilization in the Upper Paraná River floodplain, Brazil. Aquatic Botany 102: 50-55.

Oksanen J, Blanchet FG, Kindt R, Legendre P, Minchin PR. 2017. Vegan: community Ecology Package. R package version 2.5-7. https://cran.rproject.org/web/packages/vegan/index.html. 07 Jun. 2020.
Padial AA, Carvalho P, Thomaz SM, Boschilia SM, Rodrigues RB, Kobayashi JT. 2009. The role of an extreme flood disturbance on macrophyte assemblages in a Neotropical floodplain. Aquatic Sciences 71: 389-398.

Padial AA, Siqueira T, Heino J, et al. 2012. Relationships between multiple biological groups and classification schemes in a Neotropical floodplain. Ecological Indicators 13: 55-65.

Padial AA, Ceschin F, Declerck SAJ, et al. 2014. Dispersal ability determines the role of environmental, spatial and temporal drivers of metacommunity structure. PLOS ONE 9: e111227. doi: 10.1371/ journal.pone.0111227

Pandit AK. 1984. Role of macrophytes in aquatic ecosystems and management of freshwater resources. Journal of environmental management 18: 73-88.

Pausas JG, Verdú M. 2010. The jungle of methods for evaluating phenotypic and phylogenetic structure of communities. BioScience 60: 614-625.

Pavao-Zuckerman MA, Coleman DC. 2007. Urbanization alters the functional composition, but not taxonomic diversity, of the soil nematode community. Applied Soil Ecology 35: 329-339.

Pedralli G. 1990. Macrófitos aquáticos: técnicas e métodos de estudos. Estudos de Biologia 26: 5-24.

Pereto SCAS, Ribas LGS, Wojciechowski J, et al. 2016. Trade-off in leaf and root investment of an abundant aquatic macrophyte in a Neotropical floodplain. Fundamental and Applied Limnology 188: 309-314.

Pérez-Harguindeguy N, Díaz S, Garnier E, et al. 2013. New handbook for standardized measurement of plant functional traits worldwide. Australian Journal of Botany 61: 167-234.

Pinha GD, Tramonte RP, Bilia CG, Takeda AM. 2017. Differences in environmental heterogeneity promote the nestedness of Chironomidae metacommunity in Neotropical floodplain lakes. Acta Limnologica Brasiliensia 29: e118. doi: 10.1590/S2179-975X7617

Pillar VD, Duarte LDS, Sosinski EE, Joner F. 2009. Discriminating traitconvergence and trait-divergence assembly patterns in ecological community gradients. Journal of Vegetation Science 20: 334-348.

Pocheville A. 2015. The Ecological Niche: History and Recent Controversies. In: Heams T, Huneman P, Lecointre G, Silberstein M. (eds.) Handbook of Evolutionary Thinking in the Sciences. Dordrecht, Springer. p. 547-586.

Pott VJ, Bueno NC, Pereira RAC, Salis SM, Vieira NL. 1989. Distribuição de macrófitas aquáticas numa lagoa na Fazenda Nhumirim, Nhecolândia, Pantanal, MS. Acta Botanica Brasilica 3: 153-168.

Pott VJ, Pott A, Lima LCP, Moreira SN, Oliveira AKM. 2011. Aquatic macrophyte diversity of the Pantanal wetland upper basin. Brazilian Journal of Biology 71: 255-263.

R Development Core Team. 2018. R: A language and environment for statistical computing. R Foundation for Statistical Computing, Vienna, Austria. https://www.R-project.org/. 07 Jun. 2020.

Roberto MC, Santana NF, Thomaz SM. 2009. Limnology in the Upper Paraná River floodplain: large-scale spatial and temporal patterns, and the influence of reservoirs. Brazilian Journal of Biology 69: 717-725.

Roberts DW. 2016. labdsv: Ordination and Multivariate Analysis for Ecology. R package version 1.8-0. http://CRAN.R-project.org/ package=labdsv. 07 Jun. 2020.

Santos AM, Thomaz SM. 2007. Aquatic macrophytes diversity in lagoons of a tropical floodplain: The role of connectivity and water level. Austral Ecology 32: 177-190.

Schneider B, Cunha ER, Marchese M, Thomaz SM. 2018. Associations between Macrophyte Life Forms and Environmental and Morphometric Factors in a Large Sub-tropical Floodplain. Frontier in Plant Science 9: 1-10.

Shipley B, Laughlin DC, Sonnier G, Otfinowski R. 2011. A strong test of the maximum entropy model of trait-based community assembly. Ecology 92: 507-517.

Souza DC, Cunha ER, Murillo RA, et al. 2017. Species inventory of aquatic macrophytes in the last undammed stretch of the Upper Paraná River, Brazil. Acta Limnologica Brasiliensia 29: e115. doi: 10.1590/ S2179-975X6017

Souza-Filho EE. 2009. Evaluation of the Upper Paraná River discharge controlled by reservoirs. Brazilian Journal of Biology 69: 707-716. 
Steffens B, Rasmussen A. 2016. The Physiology of Adventitious Roots. Plant Physiology 170: 607-617.

Tabata R, Sumida K, Yoshii T, Ohyama K, Shinohara H, Matsubayashi Y. 2015. Perception of root-derived peptides by shoot LRR-RKs mediates systemic n-demand signaling. Science 346: 343-346.

Tilman D, Knops J, Wedin D, Reich P, Ritchie M, Siemann E. 1997. The Influence of Functional Diversity and Composition on Ecosystem Processes. Science 277: 1300-1302.

Tilman D. 2001. Functional Diversity. In: Levin SA. (ed.) Encyclopedia of Biodiversity. New York, Minnesota, Elsevier. p. 109-120.

Thomaz SM, Pagioro TA, Bini LM, Souza DC. 2002. Macrófitas aquáticas da planície de inundação do Alto Rio Paraná: listagem de espécies e padrões de diversidade em ampla escala. Maringá, Relatório Peld/ CNPq/Nupelia. http://www.peld.uem.br/Relat2002/pdf/comp_ biotico_macrofitas.pdf.

Thomaz SM, Carvalho P, Padial AA, Kobayashi JT. 2009. Temporal and spatial patterns of aquatic macrophyte diversity in the Upper Paraná River floodplain. Brazilian Journal of Biology 69: 617-625.
Vellend M. 2010. Conceptual synthesis in community ecology. The Quarterly Review of Biology 85: 183-206.

Weiher E, Freund D, Bunton T, Stefanski A, Lee T, Bentivenga S. 2011. Advances, challenges and a developing synthesis of ecological communities assembly theory. Philosophical Transactions of The Royal Society B 366: 2403-2413.

Werker E. 2000. Trichome Diversity and Development. Advances in Botanical Research 31: 1-35.

Yachi S, Loreau M. 1999. Biodiversity and ecosystem productivity in a fluctuating environment: The insurance hypothesis. Proceedings of the National Academy of Sciences 96: 1463-1468.

Yang Z, Liu X, Zhou M, et al. 2015. The effect of environmental heterogeneity on species richness depends on community position along the environmental gradient. Nature Scientific Reports 5: 1-7. Zhang JT. 2004. Quantitative ecology. Beijing, Science Press.

Zhu L, Fu B, Zhu H, Wang C, Jiao L, Zhou J. 2017. Trait choice profoundly affected the ecological conclusions drawn from functional diversity measures. Scientific Reports, 7: 1-13. 